Eurasscience Journals

Eurasian Journal of Forest Science (2017) 5(2): 19-25

\title{
A new alien species record for the flora of Turkey: Proboscidea louisianica (Miller) Thell.
}

\author{
Ece Sevgi ${ }^{1}$, Çağla Kızılarslan-Hançer ${ }^{1}$, Hatice Yılmaz $^{2}$, Muhammet Akkaya ${ }^{3}$ \\ 1) Bezmialem Vakif University, Faculty of Pharmacy, Department of Pharmaceutical Botany, 34093, İstanbul, Turkey \\ 2) Istanbul University, Vocational School of Forestry, Ornamental Plants Cultivation Prog., 34473, İstanbul, Turkey \\ ${ }^{3)}$ Forest Management, Biga-Çanakkale, Turkey \\ *corresponding author: esevgi@bezmialem.edu.tr
}

\begin{abstract}
Proboscidea louisianica (Miller) Thell. (Martyniaceae) is reported as a new alien species for the flora of Turkey. A plant species with different and interesting fruits was photographed in 2016. During a field investigation, a population of $P$. louisianica consisting of ca. 25 individuals was found at roadside between Biga and Karabiga town, district of Çanakkale, and plant specimens with flowers were collected in 2017. After detailed literature studies, this species was identified as Proboscidea louisianica. The family Martyniaceae is represented by just 1 genus with 1 taxa (Ibicella lutea (Lindl.) Van Eselt.) in Turkey and no member of the genus Proboscidea has been recorded before. In this paper, the species was introduced with taxonomical and morphological features. Its ecological impact was also evaluated with potential risks.
\end{abstract}

Keywords: Proboscidea, Martyniaceae, new record, flora, Turkey

\section{Özet}

Bu çalışmada Proboscidea louisianica (Miller) Thell. (Martyniaceae) Türkiye Florası için yeni bir yabancı tür olarak kaydedilmiştir. Çanakkale, Biga-Karabiga arası yol kenarında yaklaşı 25 adet bitkiden oluşan populasyondan 2016 yılında genç meyveli, çiçek taşımayan bireylerden fotoğraflar çekilerek kayıt alınmıştır. 2017 yılında çiçeklenme dönemi olan Ağustos ve Eylül aylarında tekrar arazi çalışması yapılarak hem bitki örnekleri alınmış hem de detaylı populasyon bilgileri kaydedilmiştir. Yapılan incelemeler sonucunda bitkinin şimdiye kadar yapılan flora ile ilgili yayınlarda yer almadığı görülmüştür. Daha sonra yapılan literatür taraması ile bitki Proboscidea louisianica (Martyniacaee) olarak teşhis edilmiştir. Familyanın Türkiye için yeni bir istilacı tür olarak 2014 yılında kayıt edilen Ibicella lutea (Lindl.) Van Eselt. türü dışında başka bir taksonu Türkiye florasında yer almamaktadır. Türün bölgeye nasıl ve ne zaman geldiği bilinmemektedir. Hizlı yayılma kabiliyetinde olan bu yabancı türün bulunduğu bölgede istilacı olma potansiyelinin yüksek olduğu düşünülmektedir.

Anahtar Kelimeler: Proboscidea, Martyniaceae, yeni kayıt, flora, Türkiye 


\section{Introduction}

Alien species are the species that spread by human activities accidentally or deliberately beyond the limits of its native geographic range into a given geographical unit where they do not naturally occur. Common synonyms are exotic, adventive, introduced, non-indigenous, or non-native (Richardson et al. 2011). Some alien species can easily colonize and naturalized in their new region and can also be invasive because they have the potential to spread over a considerable area. Therefore, the national alien plant checklists are crucial to evaluate the status of biodiversity and threats to endangered species in a given country, but globally integrated efforts are needed to control, manage and understand the spread of alien species. (van Kleunen et al. 2015). Recently, a checklist of the alien plants of the Turkey which comprises 340 taxa, was published (Uludağ et al. 2017).

Martyniaceae is represent by 5 genus and 16 species in the world, distributed mainly in southern USA to Argantine (Ihlendfelt 2004). The most characteristic feature of the family is its fruits which terminate in an upwardly-curved beak which may be longer (in Ibicella and Proboscidea) or shorter than the fruit body (Thieret 1977). The genus Proboscidea is represented by 8 species that spread naturally from the south of America to Mexico (Ihlendfelt 2004, Gutierrez 2011).

In this article, it is claimed that this species is the first record of the genus to be added to the alien flora of Turkey. This plant species can spread quickly where is located and compete well with the native vegetation of the locations at which it occurs.

\section{Material and Methods}

Studied plant species was photographed for the first time by forest engineer Muhammet Akkaya during the fruit period in 2016 in Biga (Figure 1). In August and September 2017, plant specimens was collected during flowering time. This species is included neither in Flora of Turkey (Davis 1965-1985, Davis et al. 1988, Güner et al. 2000) nor in relevant publications/literatures that have published before (Güner et al. 2012, Uludağ et al. 2017). After detailed studies it has been determined as genus Proboscidea which belongs to Martyniaceae family that is not found in Turkey. It was identified as Proboscidea louisianica which is a native species of South America and Mexico according to several literatures (Komarow 1934-1960, Abrams 1960, Tutin et al. 1964-1980, Heywood 1978, Wunderlin 1998,

Ihlenfeldt 2004). The specimens were deposited at the Faculty of Forestry Herbarium of Istanbul University (ISTO).

\section{Results and Discussion}

New record in Turkey: A1 Çanakkale: Karabiga-Biga. Between Güleçköy and Yeniçiftlik on roadsides, dried Ece lake around, 7.9.2017, 20m, Sevgi E., ISTO Number: 37325.

Description of the species (Proboscidea louisianica (Miller) Thell. Mém. Soc. Sci. Nat. Math. Cherbourg 38: 480. 1912) is given by following Abrams and Ferris (1960), Tutin (1972) and Ihlenfeldt (2004) (Figure 2). Fatty acid derivatives and dammarane triterpenes from the glandular trichome exudates of Ibicella lutea and Proboscidea louisiana" (Asai et al. 2010), this specimen is named as Proboscidea louisiana in some articles. But as a result of the examinations, it is determined that the writing of the epithet as "lousiana" is incorrect.

English names: Purple flower devil's claw, goathead, goat's-head, ram's-horn, elephant-tusk, unicorn plant (Parsons and Cuthbertson 2001, Wiersema and Leon 2013). 


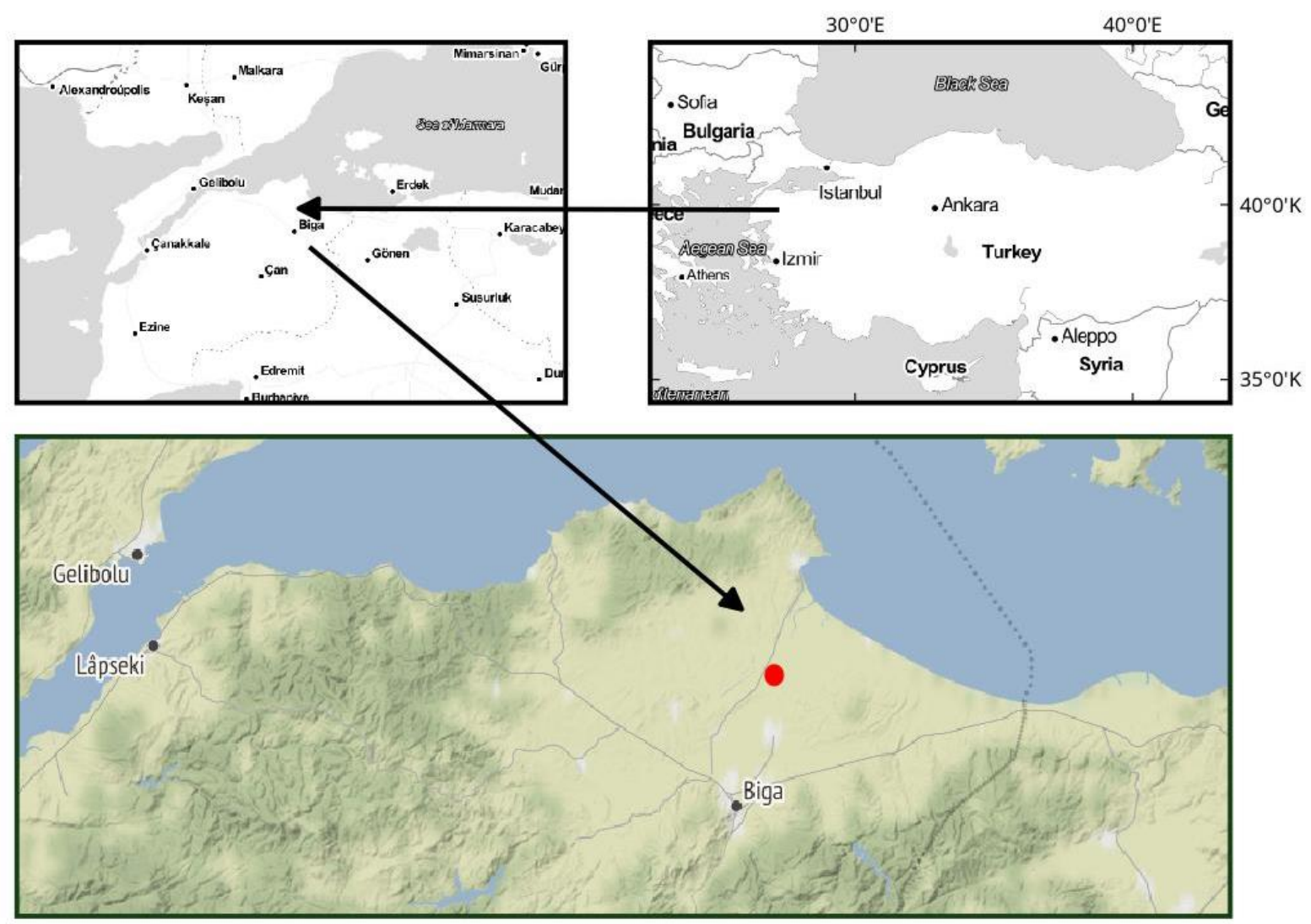

Figure 1. The area where the specimens collected

Description: Glandular-pubescent annual with prostrate or ascending stems, 30-90 cm long. Leaves opposite, the upper sometimes subalternate, $6-20 \mathrm{~cm}$ across, broadly ovate or rounded, deeply cordate at base, entire or shallowly sinuate. Petioles $5-15 \mathrm{~cm}$, stout, Inflorescence racemose, (8)-20-40 flowered and flowers fragrant. Calyx $1.5-2 \mathrm{~cm}$ long, connate at least $1 / 2$. Corolla campanulate to funnel form, limb unequally 5-lobed; white, cream or purple, throat yellow and often dotted with rose-purple, about 3.5$5.5 \mathrm{~cm}$ long. Fertile stamens 4, included. Fruit is a 2-valved capsule with long horns, 4-6 cm, horns are 1-3 times longer than the body, on the upper site with a serrate crest up to $1 \mathrm{~cm}$ high, surface usually not distinctly echinate. Flowering time is August to September in Turkey.

Habitat: Pastures, roadsides, dried lake around in Turkey (Figure 3).

P. fragrans (Lindl.) Decne. which is taxonomically similar to $P$. louisianica has been accepted as a species according to Lawrence 1957 and Hevly 1970 (Gutierrez 2014). The leaves of P. louisianica have entire margins, and the corollas are creamy-white tinged with lavender whereas leaves of $P$. fragrans are 3-5 lobed with roughly serrate margins and the corollas are dark-medium purple. However according to Bretting (1983), $P$. fragrans was accepted as a subspecies of $P$. louisianica. According to recent molecular studies using phylogenetic analyses of nuclear and chloroplast sequences fails to place $P$. fragrans as a sister to $P$. louisianica. Thus these species were recognized to be different species (Gutierrez 2011, 2014).

The leaves, stems, flowers and immature fruits of $P$. louisianica are covered with dense glandular trichomes, and that exude unpleasant smelling oily materials. The glandular trichome exudate on leaves of $P$. louisianica were the most abundant constituents the dammarane triterpenes (47\%) and the glucosyloxyfatty acids (38\%) (Asai et al. 2010). 


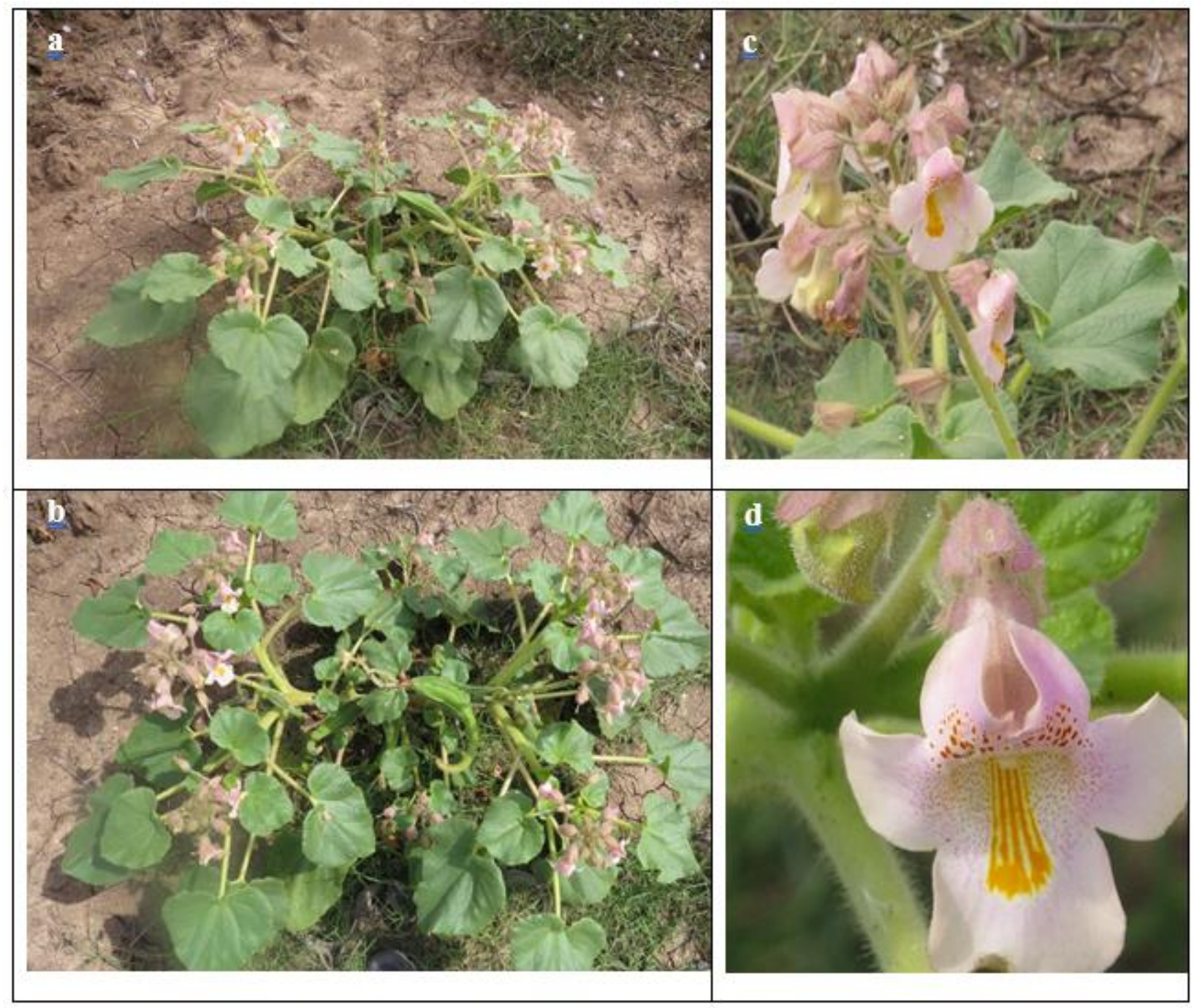

Figure 2. Proboscidea louisianica; a,b: habitus, c,d: flower morphology

Proboscidea louisianica is a native of south America and Mexico (Gutierrez 2011), introduced and naturalized in some European and Mediterranean countries, i.e. Portugal, South east Russia (Tutin 1972), South France, Italy, South Russia and Caucasica (Greuter et al. 1989, Czerepanov 1995, Paiva et al. 2001), Greece (Raab-Straube and Raus, 2016), Australia (Thieret 1977, Parsons and Cuthbertson 2001). With this finding, Turkey may be added as a new distribution area of the species. The family Martyniaceae is represented by just 1 genus with 1 taxa (Ibicella lutea (Lindl.) Van Eselt.) in Turkey (Pirhan and Yıldırım 2014) and no member of the genus Proboscidea has been recorded up to now. 


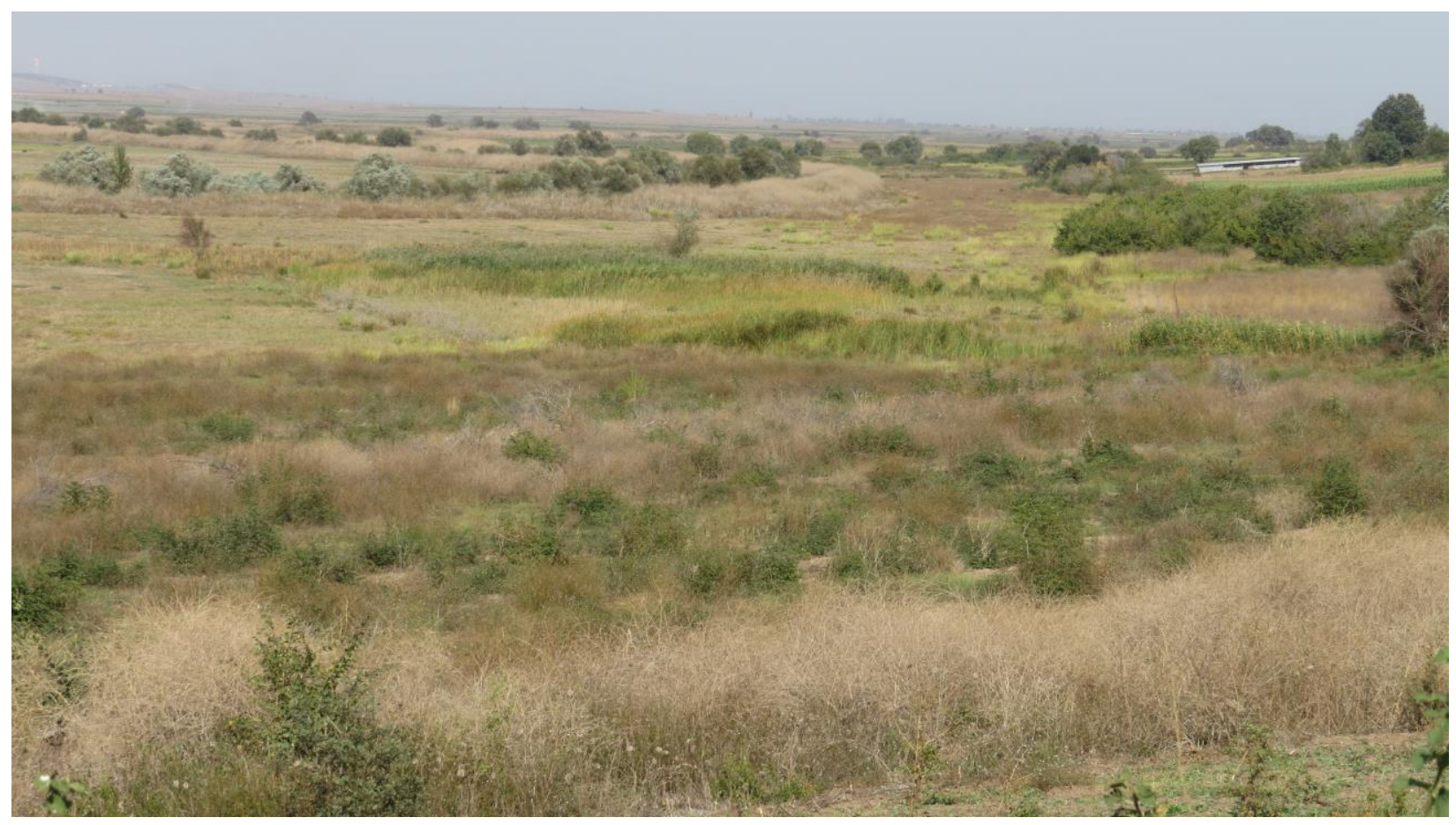

Figure 3. Habitat of Proboscidea louisianica

There is no common name of the species in Turkish because of the new registration for Flora of Turkey. "Keçibaş1" is suggested Turkish name for this species as the translation of one of its names used in English which refers to the long horned fruit that resembles goat-head (Figure 4).
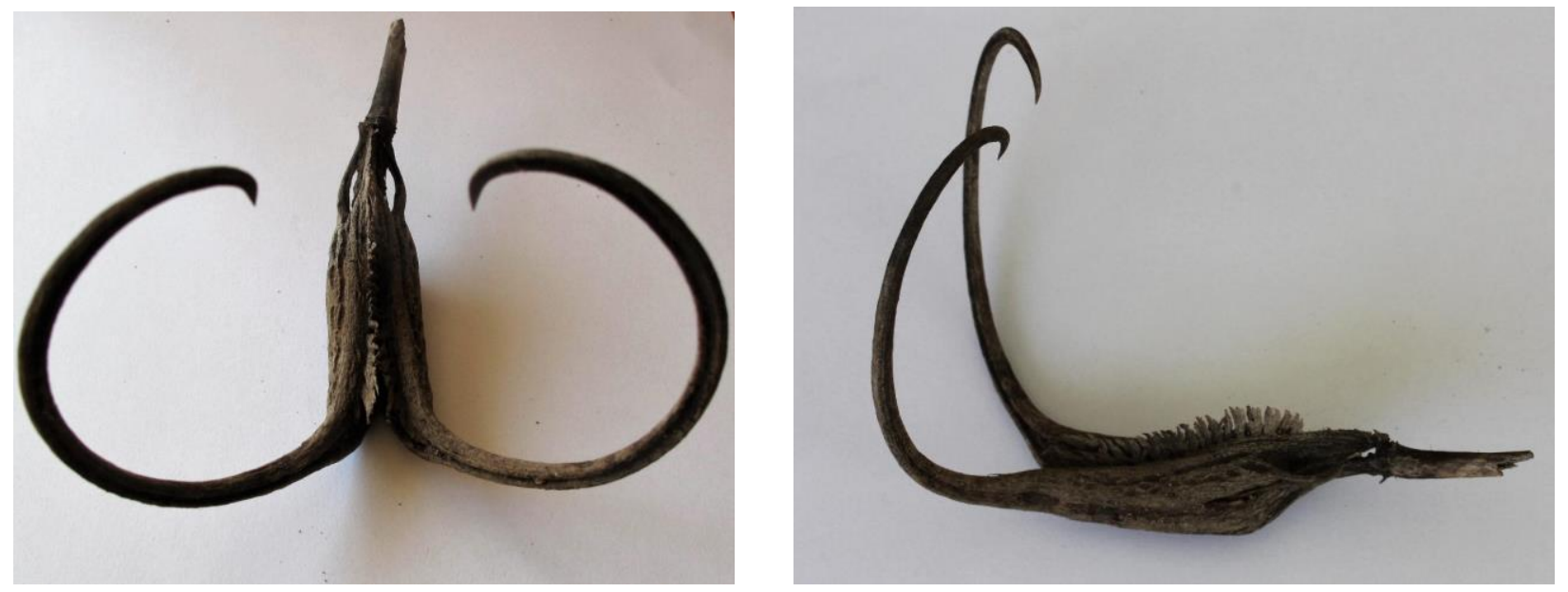

Figure 4. Mature capsule of Proboscidea louisianica

Young fruits of Proboscidea louisianica may be made prickles and dried fruits may be used in floral arrengements. Hard and woody fruit with their long and hooked horns can injure grazing animals especially sheep (Thieret 1977, EPPO 2009). They also can be strongly competitive with summer crops. Also hard and woody fruits can mix with stock and can prick to the feet or mouth. 
This plant species can spread quickly where is located and compete well with the native vegetation of the locations at which it occurs (EPPO 2009).

\section{References}

Abrams, L., Ferris, R.S. (1960). Illustrated flora of The Pacific States. Bignoniaceae to Compositae, Vol 4, (Martyniaceae pp 1-3). Stanford Univ. Press, California. 735 s.

Asai, T., Hara, N., Fujimoto, Y. (2010). Fatty acid derivatives and dammarane triterpenes from the glandular trichome exudates of Ibicella lutea and Proboscidea louisiana, Phytochemistry, 71, 877-894.

Bretting, P. K. (1983). The Taxonomic Relationship between Proboscidea louisianica and Proboscidea fragrans (Martyniaceae), The Southwestern Naturalist, Vol. 28, No. 4, pp. 445-449.

Czerepanov, S. K. (1995). Vascular plants of Russia and adjacent states (the former USSR). - Cambridge: Cambridge University Press. pp 516.

Davis, P.H., Mill, R.R., \& Tan, K. (eds.) (1988). Flora of Turkey and the East Aegean Islands 10. Edinburgh University Press, Edinburgh.

Davis, P.H. (ed.) (1965-1985). Flora of Turkey and the East Aegean Islands 1-10, Edinburgh University Press, Edinburgh.

EPPO (2009). EPPO Global Database (available online). https://gd.eppo.int/reporting/article-123 (Visited on date: 12/09/2017).

Greuter, W., Burdet, H. M., Long, G. (1989). Med-Checklist. A critical inventory of vascular plants of the circumMediterranean countries. 4. - Genève: Conservatoire et Jardin botaniques de la Ville de Genève; Berlin:Secrétariat Med-Checklist, Botanischer Garten und Botanisches Museum Berlin-Dahlem.

Gutierrez, Jr., R. (2011). A Phylogenetic Study Of The Plant Family Martyniaceae (Order Lamiales). Ph.D. dissertation, Arizona State Univ., Tempe.

Gutierrez, R. (2014). Proboscidea fragrans (Martyniaceae) in El Paso County, Texas. Phytoneuron 2014-55: 1-3.

Güner, A., Özhatay, N., Ekim, T., Baser, K. H. C. (eds.) (2000). Flora of Turkey and East Aegean Islands 11, Edinburgh Univ. Press, Edinburgh.

Güner, A., Aslan, S., Ekim, T., Vural, M. \& Babaç, M.T. (eds.) (2012). Türkiye Bitkileri Listesi (Damarlı Bitkiler). Nezahat Gökyiğit Botanik Bahçesi ve Flora Araştırmaları Derneği, İstanbul.

Heywood, V. H. (ed.) (1978). Flowering Plants of the World. Oxford Universty Press, Oxford.

Ihlenfeldt, H.D. (2004). Martyniaceae. In: Kadereit, J. W. (ed.), The families and genera of vascular plants Lamiales (except Acanthaceae including Avicenniaceae), V. 7, Springer, pp: 283-3289.

Komarow, V.L. (ed.) (1934-1960). Flora of The U.S.S.R. Leningrad \& Moscow. (English translation by IPST 1-29, Jerusalem \& Israel 1941-1951).

Paiva, J., Herrero, A., Aedo, C. (2001). Martyniaceae. In Castroviejo S. \& al. (ed.), Flora Iberica. Plantas vasculares de la Península Ibérica e Islas Baleares 14. Myoporaceae - Campanulaceae. - Madrid: Real Jardín Botánico, C.S.I.C. pp. $21-24$.

Parsons, W.T., Cuthbertson, E.G. (2001). Noxious Weeds of Australia. Csiro Publishing, 698 pages. 
Pirhan, A.F., Yıldırım, H. (2014). Türkiye için yeni bir istilacı tür kaydı: Ibicella lutea (Lindl.) Van Eslt. (Martyniaceae). Bağbahçe Bilim Dergisi 1(2):31-36.

Raab-Straube, E. von \& Raus, Th. (ed.) (2016). Euro+Med-Checklist Notulae, 6, Willdenowia 46: 423 - 442.

Richardson, D.M., Pyšek, P., Carlton, J. (2011). A compendium of essential concepts and terminology in invasion ecology. Richardson DM, editor. Fifty years of invasion ecology: the legacy of Charles Elton. Oxford: John Wiley \& Sons Ltd. pp. 409-420.

Thieret, J. W. (1977). The Martyniaceae in the southeastern United States. Journal of the Arnold Arboretum 58: 2539.

$\operatorname{Tropicos}^{\circledR}$ (2017). (available online). http://www.tropicos.org/Name/19900006. (Visited on date: 13.09.2017).

I.P.N.I. (2017). The International Plant Names Index. (available online). http://www.ipni.org/ipni/idPlantNameSearch.do?id=210336-2\&back_page=. (Visited on date: 13.09.2017).

Tutin, T.G., Heywood, V.H., Burges, N.A., Moore, D.M., Valentine, D.H., Walters, S. \& Webb, B.A (1972). Martyniaceae, Flora Europaea, Vol.3, Cambridge University Press, Cambridge.

Uludağ, A., Aksoy, N., Yazlık, A., Arslan, Z.F., Yazmış, E., Üremiş, I., Cossu, T.A., Groom, Q., Pergl, J., Pyšek, P., Brundu, G. (2017). Alien flora of Turkey: checklist, taxonomic composition and ecological attributes. NeoBiota 35: 61-85. https:// doi.org/10.3897/neobiota.35.12460

van Kleunen, M., Dawson, W., Essl, F., Pergl, J., Winter, M., Weber, E., Kreft, H., Weigelt, P., Kartesz, J., Nishino, M., Antonova, LA., Barcelona, JF., Cabezas, FJ., Cárdenas, D., Cárdenas-Toro, J., Castaño, N., Chacón, E., Chatelain, C., Ebel, AL., Figueiredo, E., Fuentes, N., Groom, QJ., Henderson, L., Inderjit, Kupriyanov, A., Masciadri, S., Meerman, J., Morozova, O., Moser, D., Nickrent, DL., Patzelt, A., Pelser, PB., Baptiste, MP., Poopath, M., Schulze, M., Seebens, H., Shu, W., Thomas, J., Velayos, M., Wieringa,. JJ, Pyšek, P. (2015). Global exchange and accumulation of non-native plants. Nature 525: 100-103. https://doi.org/10.1038/nature14910.

Wunderlin, R. P. (1998). Guide to the Vascular Plants of Florida, University Press of Florida, Gainesville, p. 816.

Wiersema, J.H., Leon, B. (2013). World Economic Plants: A Standard Reference, Second Edition, CRC Press, UK, P 1336.

Submitted: 26.09.2017; Accepted: 12.10.2017 